\title{
Tax Rates Variations And Its Effect On Individual Tax Payers A Research Focussed On Salaried Class People In India
}

\author{
Parameswaran Subramanian' ${ }^{1}$, Maria Josephine Williams ${ }^{2}$,Sangeetha $\mathbf{S}^{\mathbf{3}}$ \\ ${ }^{1}$ Professor Department of Commerce Sri Krishna Arts \& Science College, Coimbatore \\ ${ }^{2}$ Professor Department of Commerce Sri Krishna Arts \& Science College, Coimbatore \\ ${ }^{3}$ Assistant ProfessorDepartment of Commerce Sri Krishna Arts \& Science College,Coimbatore
}

Article History: Received: 11 January 2021; Accepted: 27 February 2021; Published online: 5 April 2021

\begin{abstract}
The structure and financing of a tax rate variations are grave to achieving economic growth. Tax rate cuts may encourage individuals to figure, save, and invest, but if the tax cuts aren't financed by immediate spending cuts they're going to likely also end in an increased federal deficit, which within the long-term will reduce national saving and lift interest rates. Even though, they reallocate resources diagonally toward their highest-value economic use, resulting in improved efficiency and potentially raising the overall size of the economy. The sample for the study happens to be 384 number of taxpayers. The cogent way of statistical analysis is made via ANOVA and T-test. This paper makes an attempt to explore the tax rate changes and its effect on individual tax payers.

Keywords: Tax payers, National savings, Taxation system and Tax rate.
\end{abstract}

\section{Introduction}

Indian taxation system is one of world's largest taxation system in term of its wide application on large number of people and other business entities. It is well structured system derived from the Indian constitution. India has a federal system of Government with clear demarcation of power between Central Government and State Governments.

Every year, the Income Tax Department sends tax scrutiny notice to thousands of businessmen and salaried individuals who file their Income Tax Returns every year. Receiving a notice doesn't imply that a person is guilty; it is merely a routine checkup by the Income Tax department. There has been a considerable reduction in the number of tax payers selected for scrutiny in the last five years, according to government data. While as many as $0.71 \%$ of the tax payers were selected for scrutiny in $2015-16$, that number has come down to $0.25 \%$ in 2018-19. It is expected that 1.5 crore Indians pay Income tax. That is just a little over $1 \%$ of India's population and only $1.6 \%$ of the country/'s adult (over 20 years) population. (Times of India, 2020).

\section{Statement of the problem}

Tax collection is a primary factor through which revenue can be generated. The tax rate is the percentage of an income or an amount of money that has to be paid as tax. When the tax rate increases can decrease economic activity through short-run demand-side effects that leads to reduce actual GDP below potential GDP as lower disposable income causes declines in consumption and investment. Long-run supply-side effects i.e., reducing potential GDP through behavioral responses (Andrew Fieldhouse,2013). Therefore, it becomes essential to study the tax rate changes and the benefit of higher tax and its effect on individual tax payers.

\section{Objective of the Study}

- To study the tax rate variations and its impact on individual tax payers.

- $\quad$ To study the benefit of higher tax and the acceptability of tax rate.

\section{Methodology of the Study}

The present study is based on both primary and secondary data. The primary data has been gathered from 383 respondents through structured questionnaire by adopting Random sampling technique. The secondary data has been gathered from books, journals and websites.

Tools used for analysis:

The primary data has been analyzed by using mean, standard deviation, ANOVA and T - test.

Hypothesis

H01: There is no significant difference between respondent's age and their acceptability of the tax rates.

H02: There is no significant difference between respondent's nature of employment and their acceptability of the tax rates.

H03: There is no significant difference between respondent's level of employment and their acceptability of the tax rates.

H04: There is no significant difference between respondent's income per annum and their acceptability of the tax rates.

H05: There is no significant difference between respondent's benefits with higher tax and their acceptability of the tax rates. 
H06: There is no significant difference between respondent's allowances forced to utilize and their acceptability of the tax rates.

\section{II Literature Review}

India TV33 (2015), in its article revealed that the due to high tax rates for individuals the number of tax payers rate has been drastically decreased. The article is of opinion that this is due to high rate of taxes on a particular category of taxpayers and this is also due to additional surcharges and cess along with the taxes. The article concluded that only $3 \%$ population bears the total income tax burden and it may go further lesser in another 5years time. The article also concluded that majority of the taxpayer population are in the slab rate of Rs. 0 to Rs. 5 lakhs.

Rangarajan (2013) in the discussion on the tax rates increase in the financial year 2014/15 reveals that the introduction of new slab rate for the super-rich people like US, which will not affect the low and middle-income group people. He concluded that imposing of the surcharge over the limit of income might be less burdened on the individuals on the tax rates. The author further supported that this system was successful in United States of America.

Amarjothi (2013), in her research on the Indian revenue generators opined that the must has a fixed rate every year in order to make the process simplifier. The structural changes and system must ensure the payment process or collection process to be easy. Taxpayers should be provided with recognition and awards whereas, the tax evaders to be penalized with special enforcement under Taxpayer Rights. Lack of strong enforcement and political instability in policy on revenue making the collection process delay and individual tax payers must understand that the tax collection is the backbone of any country's economy.

\section{III Data Analysis and Interpretation}

\section{Tax Rates and its effect on Individual Taxpayers}

The tax rates differ from one individual to the other due to their level of income, amount of allowances and benefits received from employer, age factor and other variables. Due to additional investments such as insurance, provident funds and so on the tax rates may differ.

\section{Age Vs Tax rates}

H01: There is no significant difference between respondent's age and their acceptability of the tax rates.

TABLE 1: AGE VS TAX RATE

\begin{tabular}{|l|c|c|c|}
\hline \multirow{2}{*}{ Age } & $\begin{array}{c}\text { Tax } \\
\text { Rate }\end{array}$ & S.D & \\
\cline { 2 - 4 } & Mean & 3.45 & No. \\
\hline $21-30$ YRS & 12.00 & 2.71 & 86 \\
\hline $31-40$ YRS & 9.73 & 2.99 & 195 \\
\hline $41-50$ YRS & 10.42 & 2.76 & 53 \\
\hline Above 50 yrs & 12.50 & 3.14 & 50 \\
\hline Total & 10.70 & 384 \\
\hline
\end{tabular}

\section{ANOVA for Tax Rate}

\begin{tabular}{|l|l|l|l|l|l|}
\hline \multicolumn{1}{|c|}{$\begin{array}{l}\text { Particul } \\
\text { ars }\end{array}$} & $\begin{array}{l}\text { Sum } \\
\text { of } \\
\text { Squares }\end{array}$ & $\mathrm{f}$ & $\begin{array}{c}\text { Mean } \\
\text { Square }\end{array}$ & F \\
\hline $\begin{array}{l}\text { Betwee } \\
\text { n Groups }\end{array}$ & \multicolumn{1}{|c|}{493.8} & 3 & 164.6 & 19.0 & $*$ \\
\hline
\end{tabular}




\begin{tabular}{|l|l|l|l|l|l|}
\hline $\begin{array}{c}\text { Within } \\
\text { Groups }\end{array}$ & $501^{3277 .}$ & $8^{3}$ & 8.625 & & \\
\hline Total & S2 $^{3771 .}$ & s $^{3}$ & & & \\
\hline
\end{tabular}

(*5\% significant, $* * 1 \%$ significant, NS- Not Significant)

Table 1 reveals that respondents in the age group of above 50 years have high acceptability (12.50) on the tax rates whereas, the respondents in the age group of 31-40 have least acceptability (9.73) on the tax rates. The test results showed that there is a significant difference between the respondents age and their acceptability of tax rates.Hence, the hypothesis is rejected.

\section{Nature of Employer Vs Tax rates}

H02: There is no significant difference between respondent's nature of employment and their acceptability of the tax rates.

TABLE 2: NATURE OF EMPLOYER VS TAX RATE

\begin{tabular}{|c|c|c|c|c|}
\hline \multirow[t]{2}{*}{ Particulars } & Tax Rate & & & \\
\hline & Mean & $\mathrm{D}$ & o. & \\
\hline \multirow{3}{*}{$\begin{array}{l}\quad \text { Nature of } \\
\text { your } \\
\text { Employer }\end{array}$} & $\begin{array}{l}\text { Government/Pu } \\
\text { blic }\end{array}$ & $20^{9 .}$ & $16^{2 .}$ & 40 \\
\hline & $\begin{array}{c}\text { Semi- } \\
\text { Government }\end{array}$ & $.85^{11}$ & $12^{3 .}$ & 34 \\
\hline & Private & $.76^{10}$ & $18^{3 .}$ & $0^{31}$ \\
\hline Total & 10.70 & $14^{3 .}$ & $4^{38}$ & \\
\hline
\end{tabular}

\section{ANOVA for Tax Rate}

\begin{tabular}{|c|c|c|c|c|c|}
\hline $\begin{array}{l}\text { Partic } \\
\text { ulars }\end{array}$ & $\begin{array}{l}\text { Sum } \\
\text { of } \\
\text { Squares }\end{array}$ & $\mathrm{f}^{\mathrm{d}}$ & $\begin{array}{l}\quad \text { Me } \\
\text { an } \\
\text { Square }\end{array}$ & F & ig. \\
\hline $\begin{array}{l}\quad \text { Betw } \\
\text { een } \\
\text { Groups }\end{array}$ & $51^{136.3}$ & 2 & $76^{68.1}$ & $146^{7 .}$ & $*$ \\
\hline $\begin{array}{r}\text { Withi } \\
\text { n Groups }\end{array}$ & $000^{3635 .}$ & $81^{3}$ & $\begin{array}{rr} & 9.54 \\
1 & \end{array}$ & & \\
\hline Total & $352^{3771 .}$ & $83^{3}$ & & & \\
\hline
\end{tabular}

(*5\% significant, $* * 1 \%$ significant, NS- Not Significant)

Table 2shows that, the respondent's nature of the employer, respondents in the semi-Government category have high acceptability (11.85) on the tax rates whereas, the respondents in the Government/Public have least acceptability (9.20) on the tax rates. The test results showed that there is a significant difference between the respondents age and their acceptability of tax rates.

Hence, the hypothesis is rejected. 
Tax Rates Variations And Its Effect On Individual Tax Payers A Research Focused On Salaried Class People In India

\section{Level of Employment Vs Tax rate}

H03: There is no significant difference between respondent's level of employment and their acceptability of the tax rates.

\begin{tabular}{|c|c|c|c|c|}
\hline \multirow[t]{2}{*}{ Particulars } & Tax Rate & & & \\
\hline & Mean & S.D & ${ } \mathrm{N}$ & \\
\hline \multirow{3}{*}{$\begin{array}{l}\text { Level of } \\
\text { employment } \\
\text { in the } \\
\text { organization }\end{array}$} & Low-level & $\begin{array}{ll} & 11.9\end{array}$ & $45^{3 .}$ & $8^{9}$ \\
\hline & Middle-level & 9.95 & $78^{2 .}$ & $32^{2}$ \\
\hline & $\begin{array}{l}\text { Managerial- } \\
\text { level }\end{array}$ & $7 \begin{array}{l}11.6 \\
7\end{array}$ & $09^{3 .}$ & $4^{5}$ \\
\hline Total & 10.70 & 3.14 & $4^{38}$ & \\
\hline
\end{tabular}

\begin{tabular}{|c|c|c|c|c|c|}
\hline $\begin{array}{l}\text { Particul } \\
\text { ars }\end{array}$ & $\begin{array}{l}\text { Sum } \\
\text { of } \\
\text { Squares }\end{array}$ & $\mathrm{f}^{\mathrm{d}}$ & $\begin{array}{c}\text { Mea } \\
\text { n Square }\end{array}$ & $\mathrm{F}$ & ig. \\
\hline $\begin{array}{l}\text { Betwee } \\
\text { n Groups }\end{array}$ & $26^{325.5}$ & 2 & $763^{162 .}$ & $96^{17.9}$ & * \\
\hline $\begin{array}{l}\text { Within } \\
\text { Groups }\end{array}$ & $825^{3445 .}$ & $81^{3}$ & $\begin{array}{l}9.04 \\
4\end{array}$ & & \\
\hline Total & $352^{3771 .}$ & $83^{3}$ & & & \\
\hline
\end{tabular}

Table 3states that the respondents level of the employment, respondents in the low-level category have high acceptability (11.92) on the tax rates whereas, the respondents in the middle level have least acceptability (9.95) on the tax rates. The test results showed that there is a significant difference between the respondent's level of employment and their acceptability of tax rates. Hence, the hypothesis is rejected.

\section{Income per annum Vs Tax Rate}

H04: There is no significant difference between respondent's income per annum and their acceptability of the tax rates.

\begin{tabular}{|c|c|c|c|c|}
\hline \multirow[t]{2}{*}{ Particulars } & Tax Rate & & & \\
\hline & Mean & S.D & o. & \\
\hline \multirow[t]{2}{*}{$\begin{array}{l}\text { Income per } \\
\text { annum }\end{array}$} & $\begin{array}{c}\text { Below } \\
\text { Rs.250000 }\end{array}$ & 14.0 & $.52^{2}$ & 15 \\
\hline & $\begin{array}{l}\text { Rs. } 250001- \\
\text { Rs. } 500000\end{array}$ & 10.22 & 3.11 & 180 \\
\hline
\end{tabular}




\begin{tabular}{|c|l|l|l|l|}
\hline \multirow{2}{*}{} & $\begin{array}{c}\text { Rs. 500001 - } \\
\text { Rs. 1000000 }\end{array}$ & 10.67 & 2.95 & 165 \\
\cline { 2 - 5 } & $\begin{array}{c}\text { Above } \\
\text { Rs. } 1000000\end{array}$ & 12.33 & 3.31 & 24 \\
\hline Total & 10.70 & 3.14 & 3 & 34 \\
\hline
\end{tabular}

\section{ANOVA for Tax Rate}

\begin{tabular}{|c|c|c|c|c|c|}
\hline $\begin{array}{l}\text { Particul } \\
\text { ars }\end{array}$ & $\begin{array}{l}\text { Sum } \\
\text { of } \\
\text { Squares }\end{array}$ & $\mathrm{f}^{\mathrm{d}}$ & $\begin{array}{l}\quad \text { Me } \\
\text { an } \\
\text { Square }\end{array}$ & $\mathrm{F}$ & ig ${ }^{S}$ \\
\hline $\begin{array}{l}\text { Betwee } \\
\text { n Groups }\end{array}$ & $07^{275.3}$ & 3 & $69^{91.7}$ & $\begin{array}{c}9 . \\
975^{\circ}\end{array}$ & * \\
\hline $\begin{array}{l}\text { Within } \\
\text { Groups }\end{array}$ & $044^{3496 .}$ & $80^{3}$ & $\begin{array}{ll} & 9.20 \\
0 & \end{array}$ & & \\
\hline Total & $352^{3771 .}$ & $83^{3}$ & & & \\
\hline
\end{tabular}

Table 4 reveals thatthe respondents' income per annum, in below Rs. 250000 category have high acceptability (14.07) on the tax rates whereas, in the level of Rs. 250001 - Rs.500000 have least acceptability (10.22) on the tax rates. The test results showed that there is a significant difference between the respondent's income per annum and their acceptability of tax rates. Hence, the hypothesis is rejected.

\section{Benefits with higher tax Vs Tax rate}

H05: There is no significant difference between respondent's benefits with higher tax and their acceptability of the tax rates.

TABLE 5: BENEFITS WITH HIGHER TAX VS TAX RATE

\begin{tabular}{|c|c|c|c|c|}
\hline \multirow[t]{2}{*}{ Particulars } & $\begin{array}{l}\text { Tax } \\
\text { Rate }\end{array}$ & & & \\
\hline & Mean & $\mathrm{D}$ & ${ }^{\mathrm{N}}$ & \\
\hline \multirow[t]{2}{*}{$\begin{array}{l}\text { The benefits incur } \\
\text { high rate of tax }\end{array}$} & Yes & $.77^{10}$ & $15^{3 .}$ & $65^{3}$ \\
\hline & No & $21^{9 .}$ & $44^{2 .}$ & $9^{1}$ \\
\hline Total & 10.70 & $14^{3 .}$ & $4^{38}$ & \\
\hline
\end{tabular}

t-test for Equality of Means

\begin{tabular}{|l|l|l|}
\hline $\mathrm{t}$ & \multicolumn{1}{|c|}{$\mathrm{df}$} & Sig. \\
\hline 2.125 & $2^{3}$ & $*$ \\
\hline
\end{tabular}


Table 5. specify that the respondents with agreeable benefits with higher tax have high acceptability (10.77) on the tax rates whereas, the respondents with disagreeable have least acceptability (9.21) on the tax rates. The test results showed that there is a significant difference between the respondent's benefits with higher tax and their acceptability of tax rates. Hence, the hypothesis is rejected.

\section{Allowance forced to utilize Vs Tax rates}

H06: There is no significant difference between respondent's allowances forced to utilize and their acceptability of the tax rates.

TABLE 6: ALLOWANCES FORCED TO UTILIZE VS TAX RATE

\begin{tabular}{|c|c|c|c|c|}
\hline \multirow[t]{2}{*}{ Particulars } & Tax Rate & & & \\
\hline & Mean & S.D & o. ${ }^{\mathrm{N}}$ & \\
\hline \multirow{4}{*}{$\begin{array}{l}\text { Allowances, which } \\
\text { you were forced to } \\
\text { utilize }\end{array}$} & HRA & $\begin{array}{ll} & 10.7 \\
0 & \end{array}$ & $.01^{3}$ & $23^{2}$ \\
\hline & $\begin{array}{l}\text { Children } \\
\text { Education }\end{array}$ & 14.21 & 2.62 & 39 \\
\hline & nce ${ }^{\text {Conveya }}$ & 15.00 & 1.12 & 9 \\
\hline & D.A & 9.14 & 2.27 & 113 \\
\hline Total & 10.70 & 3.14 & $84^{3}$ & \\
\hline
\end{tabular}

\section{ANOVA for Tax Rate}

\begin{tabular}{|c|c|c|c|c|c|}
\hline $\begin{array}{l}\text { Particul } \\
\text { ars }\end{array}$ & $\begin{array}{l}\text { Sum } \\
\text { of } \\
\text { Squares }\end{array}$ & $\mathrm{f}^{\mathrm{d}}$ & $\begin{array}{l}\text { Mean } \\
\text { Square }\end{array}$ & $\mathrm{F}$ & ig. \\
\hline $\begin{array}{l}\text { Betwee } \\
\text { n Groups }\end{array}$ & $94^{919.9}$ & 3 & $65^{306.6}$ & $69^{40.8}$ & * \\
\hline $\begin{array}{l}\text { Within } \\
\text { Groups }\end{array}$ & $358^{2851 .}$ & $80^{3}$ & 7.504 & & \\
\hline Total & $352^{3771 .}$ & $83^{3}$ & & & \\
\hline
\end{tabular}

Table 6. reveals that the respondent's allowances forced to utilize, respondents received conveyance have high acceptability (15.00) on the tax rates whereas, the respondents receive D.A have least acceptability (9.14) on the tax rates. The test results showed that there is a significant difference between the respondent's allowances forced to utilize and their acceptability of tax rates. Hence, the hypothesis is rejected

\section{Conclusion}

Every citizen responsibility towards our nation is to pay the right amount of tax. If all tax payers pay taxes on time, it will aid the government to support its goals, by the way of increasing infrastructure and providing more government services for the welfare of the society. This study concludes that there is a significant difference betweenthe respondents age, level of employment, respondent's income per annum, benefits with higher tax and allowance forced to utilize and their acceptability of tax rates. Individual income tax affects many economic decisions, savings pattern, internal accommodation, consumption and assortment choice. A mix of tax-free 
income, tax deductions and credits, and the proper use of a tax deferralwill help to the individual to meet the effective tax rate.

\section{References}

1. Suman. H.N.P.S. (1974). Direct taxation and Economic Growth in India. Sterling Publishers. 41-53.

2. Charles. T. Coltfelter. (1983). Tax evasion and tax rates: An analysis of Individual returns. The Review of Economics and Statistics. 65(3). 363-373.

3. Standing committee on Finance. (2005-2006). The Taxation Laws, (amendment) bill, 2005, twenty seventh Report, Lok Sabha Secretariat, New Delhi. December 2005.

4. Srivastava, C.P (1986), Tax Administration in India, Deep and Deep publications, New Delhi, 1986.

5. Nahar, Manak Chand. (1994). Impact of Personal Income Tax on Household Savings with Special Reference to Salaried Class. Journal of Economics.

6. Harvey Rosen. (1995). Studies in state and local public finance. University of Chicago Press. 53-78.

7. Kantawala, A.S. (1998). Individual Taxation and Inflation, The Indian Economic Journal, Vol 45, No.1, July - Sept.1998, pp.93-105.

8. Andrew Fieldhouse. (2013). A review of the economic research on the effects of raising ordinary income tax rates, Economic policy Institute.

9. Rangarajan. (2013). A higher tax for super rich. The Hindu. Retrieved from http://www.thehindu.com/business/rangarajan-for-higher-taxes-for-super-rich/article4276688.ece.

10. Dr. Mrs. P. Amarjothi. (2013). A study on Indian Revenue Generators. IOSR Journal of Humanities and Social Sciences, 12 (2), 01-07.

11. William G. Gale, The Brookings Institution and Tax Policy Center Andrew A. Samwick, Dartmouth College and National Bureau of Economic Research (2014), Effects of Income Tax Changes on Economic Growth, Economic studies at Brookings.

12. India TV. (2015). Only $3 \%$ of Indian populace pays income tax. Retrieved from http://www.indiatvnews.com/business/india/only-3pc-of-indian-populace-pays-income-tax-17642.html

13. Jean Bosco Harelimana. (2018), The role of taxation on resilient economy and development of Rwanda,Journal of Finance and Marketing, Institute of Higher Education of Ruhengeri, Musanze, Rwanda.

14. K.Udayakumar, RajakrishnanManivel.(2019).Challenges faced by the individual assesses while filing income tax returns, Public economics. 